\title{
Active Attachment of Azospirillum brasilense Cd to Quartz Sand and to a Light-textured Soil by Protein Bridging
}

\author{
By YOAV BASHAN*† AND HANNA LEVANONY \\ Department of Plant Genetics, The Weizmann Institute of Science, Rehovot, Israel
}

(Received 30 November 1987; revised 25 February 1988)

\begin{abstract}
Inoculation and incubation of Azospirillum brasilense $\mathrm{Cd}$ in pure quartz sand resulted in their attachment to sand particles by fibrillar material. Addition of low concentrations of nutrients, such as fructose or malate together with $\mathrm{NH}_{4} \mathrm{Cl}$ or root extract, enhanced bacterial multiplication and attachment. This attachment was relatively weak, and depended on the presence of living bacterial cells and on growth conditions. Sequential washing after bacterial attachment decreased the number of bacterial cells in the sand. The killing of $A$. brasilense $\mathrm{Cd}$, either before or after attachment, resulted in elimination of most of the applied cells from the sand. By comparison, light-textured soil adsorbed both dead and liye bacteria. Addition of protease or EDTA to attached bacteria in sand significantly reduced the number of bacteria. The addition of various inhibitors or exposure to high temperatures yielded a reduced attachment of bacteria, proportionate to their relative inhibitory effect on growth of $A$. brasilense $\mathrm{Cd}$. Agitating $A$. brasilense $\mathrm{Cd}$ cells immediately after addition to sand reduced bacterial attachment, but increased bacterial multiplication proportionate to the increase in agitation. Attachment of $\boldsymbol{A}$. brasilense $\mathrm{Cd}$ under microaerophilic conditions was lower than under aerobic conditions, and depended on the amount, quality and composition of the available nutrients. The richer the mixture, the greater the attachment and multiplication of bacteria. Similar trends, but at a lower magnitude, were observed in light-textured soil.
\end{abstract}

\section{INTRODUCTION}

The properties of pure sand that primarily affect bacterial adsorption are the small surface area of the particles and negligible clay and organic matter content. The latter components, which have a large surface area and consist of negatively charged particles, are known as the major soil components participating in bacterial adsorption.

Adsorption of Azospirillum brasilense Cd to sand is usually low and the cells are readily desorbed by washing, a treatment which is ineffective for desorption of bacteria in normal soil. Application of very small amounts of clays and organic matter can substantially change sand adsorption properties, causing it to behave like a normal soil (Bashan \& Levanony, 1988).

$A$. brasilense $\mathrm{Cd}$, a known beneficial rhizosphere bacterium, is usually applied to the soil in order to inoculate plant roots (Bashan, 1986a). However, these bacteria are also applied to sand in plant nurseries under controlled experimental environments. One of the main drawbacks of the inoculation process is the inconsistent yield results obtained by many workers (Schank \& Smith, 1984), and/or the partial root colonization which occurs after application of this bacterial species to the soil (Bashan, 1986b).

The purpose of this study was to find out whether bacteria applied to sand are randomly dispersed on the sand particles without apparent visible adsorption, or whether they are attached to the particles in such a way as to prevent their removal by washing.

† Present address: Department of Agronomy, Ohio State University, Columbus, Ohio 43210, USA. 


\section{METHODS}

Sand and soil. Pure silica quartz sand obtained from a quarry in Yeruham crater, Central Negev, Israel (used in plant nurseries) was used. The sand contained the following (percentage composition): fine sand, 99.7; clay (kaolinite), $0 \cdot 2$; traces of organic matter and $\mathrm{CaCO}_{3}$; the sand contained no rough sand or silt. The sand had a water field capacity of $2 \%(\mathrm{v} / \mathrm{w})$ and a $\mathrm{pH}$ of 7-10. Brown-red degrading sandy soil (light-textured, Rehovot, Central Israel) was also used. This soil contained the following (percentage composition): clay, 5.7, (montmorillonite, kaolinite, calcite); silt 9.1 ; fine sand $68 \cdot 1$; rough sand, $17 \cdot 1$; organic matter, $0 \cdot 33 ; \mathrm{CaCO}_{3}, 26 \cdot 8$. The soil had a water field capacity of $8.6 \%(\mathrm{v} / \mathrm{w})$ and a pH of 8.1 (Ravikovitch, 1981). The sand and the soil were used in their natural states or after $\gamma$-irradiation $(25 \mathrm{kGy})$ using a ${ }^{60} \mathrm{Co}$ source at the Weizmann Institute of Science.

Bacterial growth conditions and inoculation. Azospirillum brasilense Cd (ATCC 29710) was cultured on nutrient broth (Difco) medium as previously described (Bashan \& Levanony, 1985). To avoid self-aggregation of bacterial cells, the cultures were shaken at 250 r.p.m. for $16 \mathrm{~h}$ in Erlenmeyer flasks fitted with shallow grooves. This procedure allowed harvesting of non-aggregating bacteria in the exponential phase of growth. Bacteria were inoculated into the sand by placing a double-washed bacterial suspension in phosphate-buffered saline (PBS) $\mathrm{pH} 7.2$ at a final concentration of $2 \times 10^{6}$ colony forming units (c.f.u.) per gram of sand or soil. Inoculation with dead bacterial cells, exposed to similar $\gamma$-irradiation as the soil and equivalent before sterilization to $10^{7}$ c.f.u. $\mathrm{ml}^{-1}$ was done as described for live bacteria.

Adsorption assays. Before any treatment, sand and soil were dried in a forced draught oven at $50 \pm 2{ }^{\circ} \mathrm{C}$ for $48 \mathrm{~h}$. The amount of solution added, i.e. bacterial culture, enzyme preparation or other solutions, was designed to simulate field capacity conditions of both the sand $(2 \%, \mathrm{v} / \mathrm{w})$ and the soil $(8.6 \%, \mathrm{v} / \mathrm{w})$. The following solutions ( $\mathrm{mM}$, final concentration) were added to the soil or to the sand, each soil sample being treated with a single solution: fructose (1 to 30); a mixture of fructose (20) and $\mathrm{NH}_{4} \mathrm{Cl}(50)$; a mixture of fructose (10), malate (10) and $\mathrm{NH}_{4} \mathrm{Cl}$ (50); FeEDTA or NaEDTA (0.5 to 5); protease (Sigma; $1 \%$, w/v); root extract [50-300 mg protein (g sand) $)^{-1}$; production described below]; and ( $\mathrm{mg} \mathrm{l}^{-1}$, final concentration) streptomycin sulphate (Sigma; 200), 2,3,5triphenyltetrazolium chloride (Riedel de Haen AG Seelze, FRG; 15) (not inhibitory), neomycin sulphate (Sigma; 200 ), $\mathrm{KCN}$ (5) (low inhibition of bacterial growth), $\mathrm{NaN}_{3}$ (10) (moderate inhibition), chloramphenicol (Sigma; 250 ), tetracycline (Sigma; 200), KCN (120) or methyl violet (60) (total growth inhibition) (Bashan \& Levanony, 1985).

Experiments under aerobic conditions were done in small glass Petri dishes containing $5 \mathrm{~g}$ dried soil; experiments under microaerophilic conditions were done in test-tubes in which the level of solution rose to $1 \mathrm{~cm}$ above the upper level of the soil in the tube. Unless otherwise stated, all test assays contained $20 \mathrm{~mm}$-fructose and $50 \mathrm{mM}-\mathrm{NH}_{4} \mathrm{Cl}$. Bacteria and solutions were added aseptically, and assay mixtures were stirred for several minutes immediately after application of bacteria. Stirring was then stopped, the dishes were sealed with Parafilm (to avoid drying of the mixture) and transferred to an incubator at $30 \pm 2{ }^{\circ} \mathrm{C}$. After various periods of incubation the number of $A$. brasilense $\mathrm{Cd}$ cells, as well as percentage of adsorbed and desorbed cells, were determined as described below.

To determine the effects of shear stress on cell attachment, adsorption assays were done as follows: glass beads $(0.5 \mathrm{~mm}$ diameter) were added to soil $(0.2 \mathrm{~g}$ per gram of sand or soil) maintained in Erlenmeyer flasks (fitted with shallow grooves); the soil was first flooded, and then shaken in a rotary shaker (150 or 300 r.p.m.).

Desorption assays. Inoculated sand or soil was placed in a $50 \mathrm{ml}$ beaker, and sterile tap-water was added until it formed a $1 \mathrm{~cm}$ water layer on the soil surface. Each solution was stirred gently either for $10 \mathrm{~s}$, or for $2 \mathrm{~min}$, or soaked for $30 \mathrm{~min}$ without stirring and then stirred for $2 \mathrm{~min}$. In addition, soil and sand were agitated in a vortex mixer (Vortex-Genie, Scientific Industries) at 180 r.p.m. for 60 s. Stirring was then stopped for $10 \mathrm{~min}$, to allow sedimentation of soil particles. The supernatant was pumped out, collected, and the number of $A$. brasilense $\mathrm{Cd}$ cells was determined by the improved selection technique (Bashan \& Levanony, 1985). In addition, the remaining soil was diluted decimally in sterile tap-water and the minimal number of adsorbed bacteria was determined. [Since the dilution method diluted only soil and peat particles, and because probably more than one bacterium adsorbed to a given particle, the lowest probable number was determined (Foster, 1986).] Numbers of $A$. brasilense $\mathrm{Cd}$ from the soil and supernatant were combined for comparison with initial bacterial concentrations.

$A$. brasilense $C d$ counts from sand and soil. $A$. brasilense $\mathrm{Cd}$ were counted by the indirect enzyme-linked immunosorbent assay (ELISA) that was developed for the detection of this specific strain (Levanony et al., 1987). In cases of low bacterial numbers $\left.\left[<10^{4} \text { cells ( } \mathrm{g} \text { sand }\right)^{-1}\right]$ counts were made by the improved selection technique based on the most probable number (MPN) method using the specific ELISA method for identification.

Total counts of $A$. brasilense $\mathrm{Cd}$ were made in the presence of combined nitrogen. They were done after the sand was thoroughly mixed and after the supernatant fraction was separated from the sediment fraction. A. brasilense $\mathrm{Cd}$ cells were counted in the two fractions and the numbers were used to determine the percentage adsorption of $A$. brasilense $\mathrm{Cd}$ in the sand or soil.

Bacterial counts in the sand made in the absence of combined nitrogen $\left(\mathrm{N}_{2}\right.$-fixing conditions) were made at a 
depth of $2 \mathrm{~cm}$ below the surface. Both a previous study (Bashan \& Levanony, 1985) and observations preliminary to these experiments showed that under microaerophilic conditions most $A$. brasilense Cd cells were to be found in this zone.

Determination of percentage adsorption. The sand sample was flooded and stirred for exactly $5 \mathrm{~min}$. The sand was allowed to settle $(10 \mathrm{~s})$ and all the supernatant was collected. The number of $A$. brasilense Cd cells in both the supernatant and sediment was determined by the ELISA technique. Percentage adsorption was calculated by dividing the numbers of cells in the sediment by the total bacterial number. Percentage desorption was calculated by dividing the numbers of bacteria in the supernatant by the total bacterial number. Confirmation of the obtained values was made according to the theoretical formula that the percentage adsorbed equals 100 minus the percentage desorbed. However, there were differences of $1-3 \%$ between the actual calculation and the theoretical value, i.e. the percentage adsorption plus the percentage of desorption equalled less than $100 \%$.

Killing of bacteria. A. brasilense Cd cells, double washed in PBS, were killed by one of the following methods: (i) exposing the cells to $\gamma$-irradiation $\left(25 \mathrm{kGy}\right.$ ); (ii) heating the cells for $30 \mathrm{~min}$ at $100{ }^{\circ} \mathrm{C}$; or (iii) adding glutaraldehyde $\left(5 \%, \mathrm{v} / \mathrm{v}\right.$, final concentration) to the cells and incubating them for $90 \mathrm{~min}$ at $25 \pm 2{ }^{\circ} \mathrm{C}$. The cells were then double washed with PBS.

Root extraction. Wheat seedlings were grown in an hydroponic system as previously described (Bashan, 1986c). At the two-leaf stage, roots excised from the plantlets were homogenized in $0.06 \mathrm{M}$-potassium phosphate buffer, pH 7.0, by a disperser (model x10/20; Ystral, Ballrechten-Dottingen, FRG) placed in an ice-bath. The slurry obtained was further homogenized by a fine glass homogenizer (Kontes, Vineland, NJ, USA). After centrifugation at $20000 \mathrm{~g}$ for $10 \mathrm{~min}$., the supernatant was collected, sterilized by passing through a Millipore filter $(0.45 \mu \mathrm{m}$ pore size), and its protein content was determined as described below. The extract was frozen and maintained at $-20^{\circ} \mathrm{C}$ until required.

Protein measurements. Supernatant obtained after a sand/soil washing was filtered through a $0.45 \mu \mathrm{m}$ Millipore filter to remove desorbed bacteria. The amount of protein in the supernatant was measured by the Coomassie blue method (Sedmak \& Grossberg, 1977).

Experimental design. All experiments were designed in a random fashion in triplicate, with three Petri dishes, tubes or SEM stubs as a single replicate. Experiments were repeated two to three times each; results given are from a representative experiment in each case. Significance is given either by the standard error of each line or by $P \leqslant 0.005$ in Duncan's multiple range test.

\section{RESULTS}

\section{Increased adsorption of $A$. brasilense $C d$ to sand by addition of fructose, malate and root extract}

Adsorption of $A$. brasilense $\mathrm{Cd}$ to sand was very low (only $5-6 \%$ of the applied bacteria adsorbed). Scanning electron microscopy of attachment of $A$. brasilense $\mathrm{Cd}$ to sand revealed a random dispersal of very small micro-colonies. Most of the bacterial cells were attached to the surface of the sand particles by single-stranded or multi-stranded fibrillar material (not shown). Increased levels of fructose or malate, in the presence of $\mathrm{NH}_{4} \mathrm{Cl}$, increased adsorption, with adsorption being higher in the presence of fructose (Fig. $1 a$ ). Addition of root extract increased adsorption to higher levels than with addition of fructose (Fig. $1 b$ ). The total number of bacteria in the sand during the course of the experiments increased linearly with time to reach high numbers (Fig. 1 inserts). Addition of fructose, malate or root extract to light-textured soil did not increase bacterial adsorption, due to the high adsorption level of the soil without treatment (over $90 \%$ adsorption; data not shown).

\section{Adsorption strength of $A$. brasilense $C d$ to sand}

$A$. brasilense $\mathrm{Cd}$ adsorbed to sand that was supplemented with various nutrients and subjected to several washing treatments. Generally, the more intensive the washing, the stronger the desorption occurring, irrespective of the different initial adsorption levels created by the nutrients. However, addition of nutrients which enhanced higher initial adsorption also resulted in a decreased rate of desorption. The greatest and strongest adsorption occurred in the soil. The slowest desorption occurred in the presence of root extract, and the fastest desorption occurred where there was no supplementation with nutrients. The other nutrient combinations gave intermediate results (Table 1). 


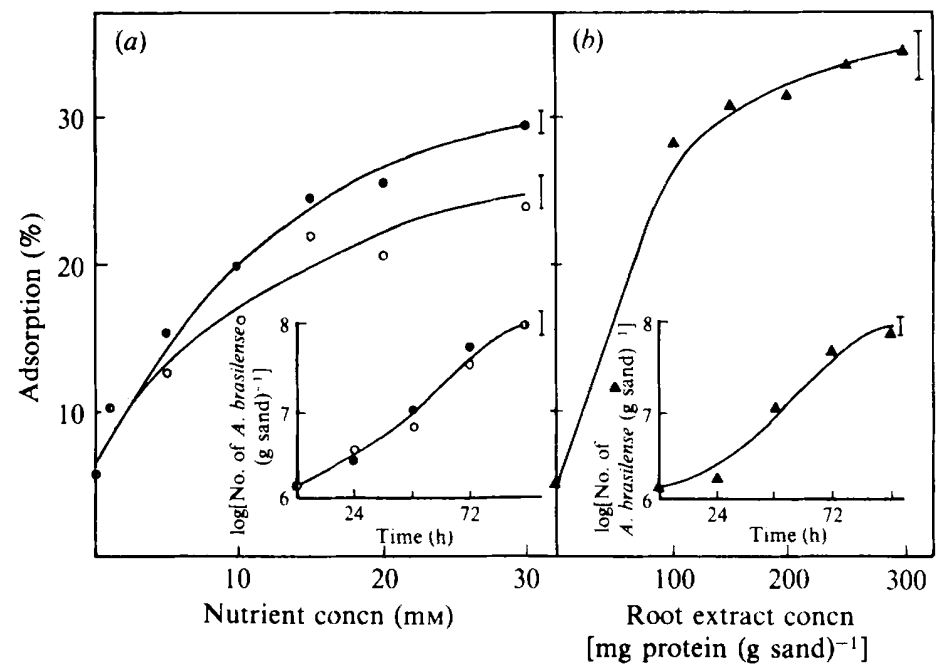

Fig. 1. Increased adsorption of $A$. brasilense $\mathrm{Cd}$ to sand $96 \mathrm{~h}$ after inoculation with the addition of fructose and $\mathrm{NH}_{4} \mathrm{Cl}(\mathrm{O})$ or malate and $\mathrm{NH}_{4} \mathrm{Cl}(\mathrm{O})(a)$ or root extract $(\mathbf{A})(b)$. Inserts show the total number of bacteria during the course of the experiment. Bars represent the standard error of the lines.

Table 1. Adsorption of $A$. brasilense $C d$ to sterile sand supplemented with nutrients following different methods of sand washing

Adsorption was measured $96 \mathrm{~h}$ after inoculation with $10^{7}$ c.f.u. $\mathrm{ml}^{-1}(1 \mathrm{ml}$ per $5 \mathrm{~g}$ sand). Significance was calculated using Duncan's multiple range test. Numbers in each column followed by different lower case letters differ significantly at $P \leqslant 0.005$. For each washing treatment numbers followed by different capital letters differ significantly at $P \leqslant 0.005$. Numbers are means of three replicates (nine individual measurements).

\begin{tabular}{|c|c|c|c|c|c|}
\hline \multirow[b]{2}{*}{$\begin{array}{l}\text { Soil washing } \\
\text { method Sup }\end{array}$} & \multicolumn{5}{|c|}{ Adsorption ( $\%)$} \\
\hline & None & $\begin{array}{l}\text { Fructose } \\
(20 \mathrm{mM})\end{array}$ & $\begin{array}{l}\text { Fructose }(20 \mathrm{mM}) \\
\text { and } \mathrm{NH}_{4} \mathrm{Cl} \\
(50 \mathrm{mM})\end{array}$ & $\begin{array}{c}\text { Fructose }(10 \mathrm{~mm}) \text {, } \\
\text { malate }(10 \mathrm{~mm}) \\
\text { and } \mathrm{NH}_{4} \mathrm{Cl} \\
(50 \mathrm{mM})\end{array}$ & $\begin{array}{l}\text { Root extract } \\
\text { [200 mg } \\
\text { protein } \\
\left.\text { (g sand })^{-i}\right]\end{array}$ \\
\hline (a) Not washed & $5 \cdot 3^{\mathrm{aC}}$ & $20 \cdot 6^{\mathrm{aB}}$ & $29 \cdot 8^{\mathrm{aA}}$ & $32 \cdot 4^{\mathrm{aA}}$ & $35 \cdot l^{\mathrm{aA}}$ \\
\hline $\begin{array}{l}\text { (b) Rinsed for } 10 \mathrm{~s} \\
\text { with slow stirring }\end{array}$ & $1.4^{\mathrm{bD}}$ & $8 \cdot 4^{\mathrm{bC}}$ & $14 \cdot 3^{\mathrm{bB}}$ & $13 \cdot 8^{\mathrm{bB}}$ & $22 \cdot 4^{\mathrm{bA}}$ \\
\hline $\begin{array}{l}\text { (c) Washed for } 2 \mathrm{~min} \\
\text { with slow stirring }\end{array}$ & $<1^{\text {be }}$ & $3.6^{\circ \mathrm{C}}$ & $6.7^{\mathrm{cB}}$ & $10 \cdot 6^{\mathrm{bAB}}$ & $15 \cdot 5^{2.4}$ \\
\hline $\begin{array}{l}\text { (d) Soaked for } 30 \mathrm{~min} \\
\text { then washed as in }(c)\end{array}$ & $<1^{b C}$ & $3 \cdot 5^{\mathrm{cC}}$ & $7 \cdot 1^{\mathrm{cB}}$ & $10 \cdot 5^{\mathrm{DAB}}$ & $16 \cdot 1^{C A}$ \\
\hline $\begin{array}{l}\text { (e) Rinsed as in }(b) \text { then } \\
\text { vortex-mixed for } 60 \mathrm{~s}\end{array}$ & $<1^{\text {bB }}$ & $<1^{c B}$ & $2 \cdot 2^{\mathrm{d} B}$ & $4 \cdot 9 \div 48$ & $8.7^{\mathrm{dA}}$ \\
\hline
\end{tabular}

\section{Adsorption of dead A. brasilense Cd to sand and soi!}

Application of dead $A$. brasilense $C d$ to sand resulted in minimal adsorption of bacteria compared to adsorption of live bacteria. Killing the bacteria after adsorption decreased significantly the level of adsorbed bacteria. Application of dead bacteria to light-textured soil only slightly decreased the adsorption. Application of $\gamma$-irradiation or heating treatments to already adsorbed bacteria decreased bacterial adsorption further. However, in general, adsorption levels of dead bacteria to soil were much higher than their adsorption to sand (Table 2). 


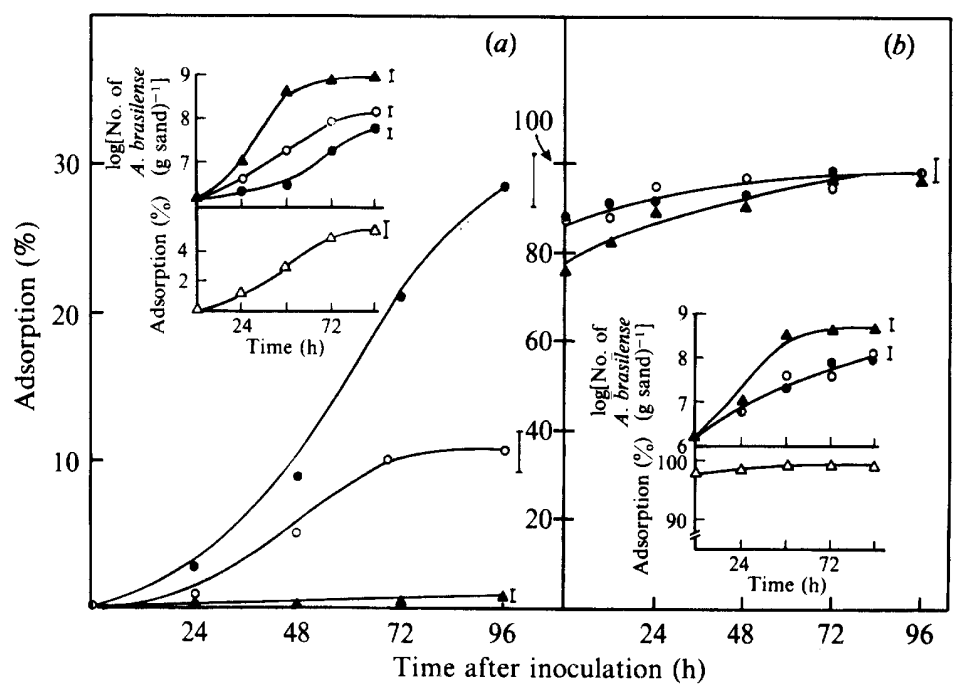

Fig. 2. Adsorption of $A$. brasilense $\mathrm{Cd}$ to sand (a) and to light-textured soil (b), during agitation, in the presence of $20 \mathrm{~mm}$-fructose and $50 \mathrm{mM}-\mathrm{NH}_{4} \mathrm{Cl}$. No agitation; $O$, low agitation; $\Delta$, strong agitation. $\triangle$, Adsorption without fructose. Bars represent the standard error of the lines.

\section{Table 2. Adsorption of dead A. brasilense $C d$ to sand and soil}

Estimation of numbers of dead bacteria was done by indirect-ELISA (Levanony et al., 1987). Numbers in columns followed by different letters differ significantly at $P \leqslant 0.005$. Numbers are means of three replicates (nine individual measurements).

\begin{tabular}{|c|c|c|}
\hline \multirow[b]{2}{*}{$\begin{array}{l}\text { Bacterial } \\
\text { treatment }\end{array}$} & \multicolumn{2}{|c|}{ Adsorption $(\%)$} \\
\hline & Sand & Soil \\
\hline Live bacteria* & $28 \cdot 3^{\mathrm{a}}$ & $91 \cdot 4^{a}$ \\
\hline$\gamma$-Irradiated bacteria ${ }^{*}$ & $<1^{b}$ & $85.9^{\mathrm{ab}}$ \\
\hline Heated bacteria* & $2 \cdot 2^{b}$ & $86 \cdot 1^{\text {ab }}$ \\
\hline $\begin{array}{l}\text { Glutaraldehyde treated } \\
\text { bacteria* }\end{array}$ & $3 \cdot 2^{b}$ & $88.9^{\mathrm{a}}$ \\
\hline $\begin{array}{l}\gamma \text {-Irradiation of } \\
\text { adsorbed bacteria } \dagger\end{array}$ & $4 \cdot 8^{\mathrm{b}}$ & $81 \cdot 2^{\mathrm{b}}$ \\
\hline $\begin{array}{l}\text { Heating of adsorbed } \\
\text { bacteria } \dagger\end{array}$ & $6 \cdot 1^{\mathrm{b}}$ & $82 \cdot 3^{b}$ \\
\hline
\end{tabular}

Adsorption of $A$. brasilense $C d$ to sand and to light-textured soil during shear stress

Mechanical agitation of sand, flooded with $A$. brasilense $\mathrm{Cd}$ in the presence of fructose and $\mathrm{NH}_{4} \mathrm{Cl}$, decreased adsorption of bacteria to the sand particles compared to the non-agitated mixture. This adsorption was slightly higher than adsorption in the absence of fructose and $\mathrm{NH}_{4} \mathrm{Cl}$. An increase in agitation reduced bacterial adsorption to very low levels $(<1 \%$ of the bacterial cells adsorbed). However, the total number of bacteria developed in the same sandbacteria mixture was higher than in the non-agitated mixture, and these bacterial cells did not adsorb to sand particles. The stronger the agitation, the higher the bacterial population that developed in the sand (Fig. 2a). A similar trend was observed in light-textured soil. However, since the initial adsorption capacity of the soil particles was much higher, the differences between agitated and non-agitated mixtures were small (Fig. $2 b$ ). Independent of external 


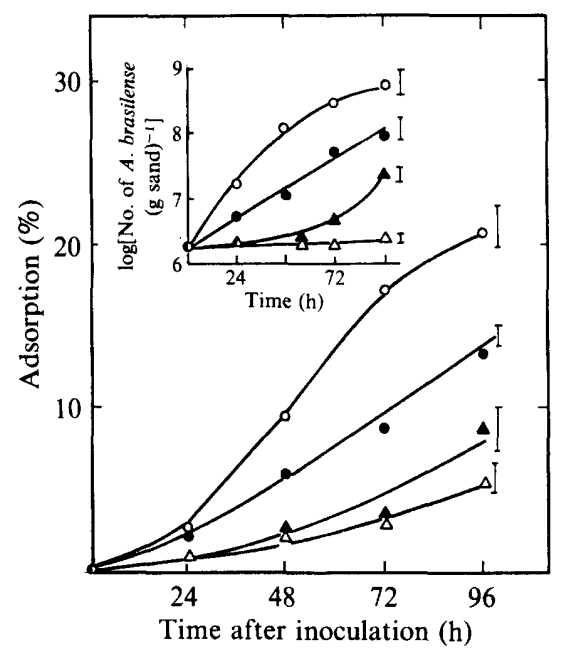

Fig. 3. Adsorption of $A$. brasilense $\mathrm{Cd}$ to sand under microaerophilic conditions. The sand-bacteria mixture was supplemented with the following substances: none $(\triangle) ; 20$ mM-fructose $(\Delta) ; 20 \mathrm{~mm}$ fructose and $50 \mathrm{mM}-\mathrm{NH}_{4} \mathrm{Cl}(\mathrm{O})$; or $10 \mathrm{~mm}$-fructose, $10 \mathrm{~mm}$-malate and $50 \mathrm{~mm}-\mathrm{NH}_{4} \mathrm{Cl}(\mathrm{O})$. Bars represent the standard error of the lines.

treatments to the sand-bacteria mixture, the percentage bacterial adsorption increased with time, with maximal adsorption $72-96 \mathrm{~h}$ after inoculation.

\section{Adsorption of $A$. brasilense $C d$ to sand under microaerophilic conditions}

Generally, adsorption of $A$. brasilense $\mathrm{Cd}$ to sand under microaerophilic conditions was lower than under aerobic conditions. Adsorption increased with time after inoculation and depended on the nutrients available to the bacteria. Addition of fructose alone increased adsorption, whereas incorporating $\mathrm{NH}_{4} \mathrm{Cl}$ with fructose increased it further (Fig. 3). Addition of fructose and malate together with $\mathrm{NH}_{4} \mathrm{Cl}$ resulted in the highest percentage adsorption; concomitantly, the number of bacteria in the sand-bacteria mixture increased (Fig. 3).

Desorption of $A$. brasilense $C d$ from sand and from light-textured soil by protease treatment

Incubation of sand or soil to which $A$. brasilense Cd had previously adsorbed for $96 \mathrm{~h}$ with protease decreased bacterial adsorption. The longer the incubation time with protease the more desorption occurred (Fig. $4 a, b$ ). The effect of protease on desorption was more marked in sand than in soil. In sand, after $2.5 \mathrm{~h}$ incubation with protease, adsorption reached a low level $(<5 \%$ adsorption; Fig. $4 a$ ), whereas in soil, bacterial desorption was minimal (Fig. $4 b$ ). In the same period of time, the level of protein in the supernatant increased in both sand and light-textured soil (Fig. $4 a, b$ ).

\section{Adsorption inhibition and desorption of $A$. brasilense $C d$ from sand by EDTA treatment}

Application of EDTA salts to a sand-bacteria mixture on which $A$. brasilense Cd cells had been previously adsorbed for $96 \mathrm{~h}$ resulted in bacterial desorption. Desorption increased with increasing EDTA concentration (Fig. $5 a$ ), and NaEDTA had a more marked effect than did FeEDTA. When NaEDTA was applied to sand mixed with bacteria, it reduced bacterial adsorption (Fig. $5 b$ ), complete inhibition occurring at 5 mM-EDTA. The total number of $A$. brasilense $\mathrm{Cd}$ cells in EDTA-treated sand was smaller than in untreated sand. The high level of NaEDTA resulted also in a decrease in the initial number of bacteria (Fig. $5 b$ insert).

Inhibition of adsorption of $A$. brasilense $C d$ to sand by various substances or by high temperature

Addition of antibiotics and other substances known to inhibit growth of $A$. brasilense $\mathrm{Cd}$ (Bashan \& Levanony, 1985) affected adsorption of this organism to sand particles (Fig. 6). 


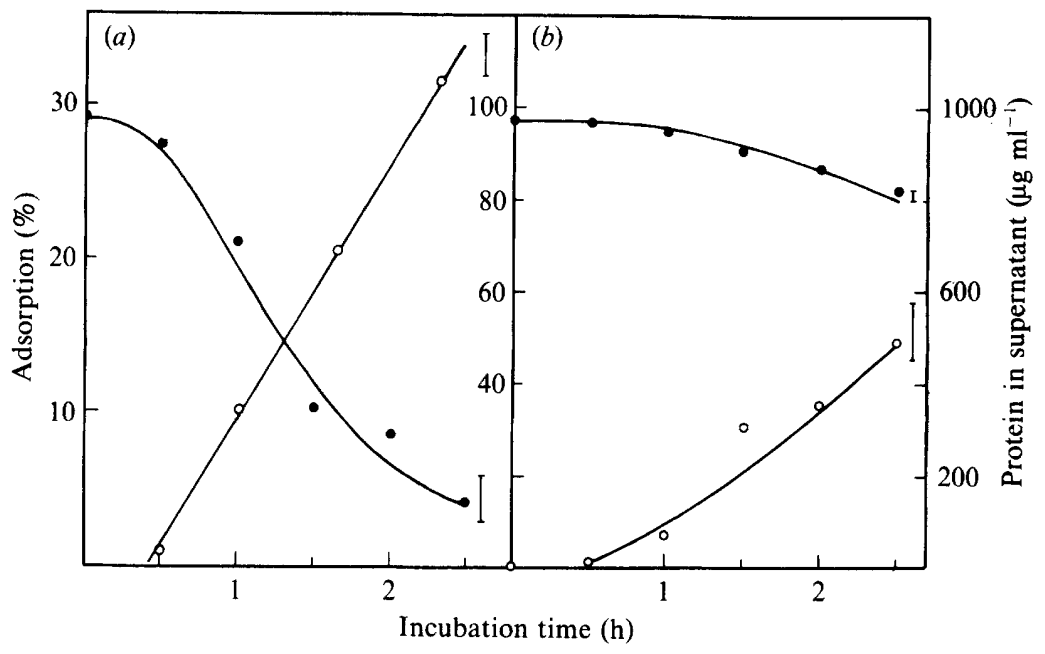

Fig. 4. Desorption (O) and increase in protein content of soil supernatant $(O)$ after incubation of soiladsorbed $A$. brasilense $\mathrm{Cd}$ with $1 \%$ protease, in sand $(a)$ and in light-textured soil $(b)$. Bars represent the standard error of the lines.

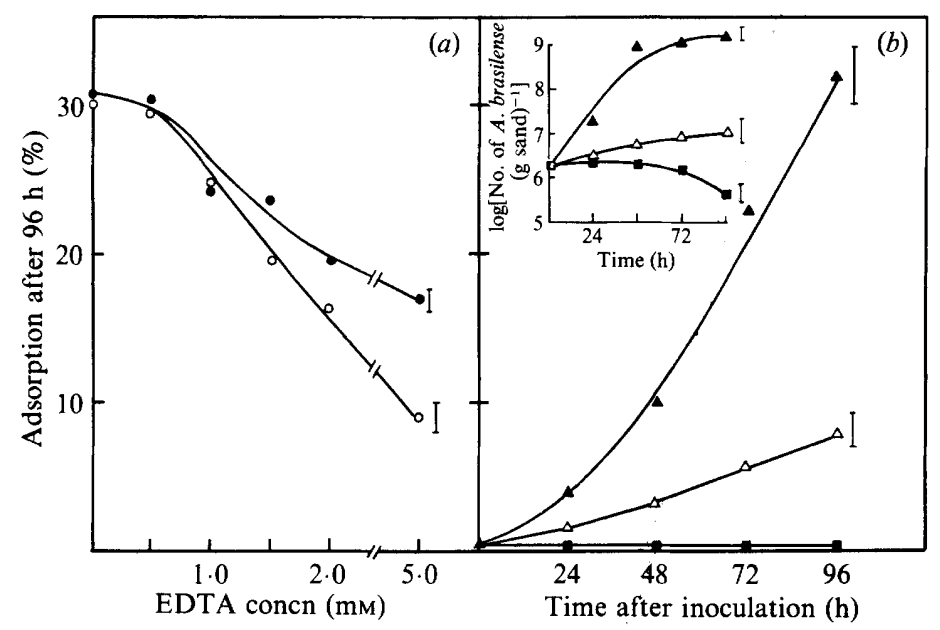

Fig. 5. (a) Desorption of $A$. brasilense Cd from sand by FeEDTA (O) and NaEDTA $(O)$; (b) inhibition of adsorption of $A$. brasilense $C d$ to sand by application of NaEDTA at various concentrations; $\Delta$, no NaEDTA; $\triangle, 1 \mathrm{mM} ; \square, 5 \mathrm{mM}$. Insert indicates the total number of $A$. brasilense $C d$. Bars represent the standard error of the lines.

Substances to which the bacteria are resistant (streptomycin sulphate and 2,3,5-triphenyltetrazolium chloride) did not affect bacterial adsorption and multiplication. Substances which inhibit $A$. brasilense $\mathrm{Cd}$ to various degrees (neomycin, $5 \mathrm{mg} \mathrm{KCN}^{-1}, \mathrm{NaN}_{3}$ ) had intermediate effects on adsorption and on multiplication, whereas inhibitory substances (chloramphenicol, tetracycline, methyl violet and $120 \mathrm{mg} \mathrm{KCN}^{-1}$ ) totally blocked adsorption and reduced the bacterial population (Fig. $6 a, b$ ). Increasing the temperature from 30 to $42{ }^{\circ} \mathrm{C}$ immediately after bacterial inoculation inhibited both bacterial adsorption and multiplication to such an extent that only $96 \mathrm{~h}$ after inoculation did the percentage adsorption exceed $5 \%$ (Fig. $6 c, d$ ). 


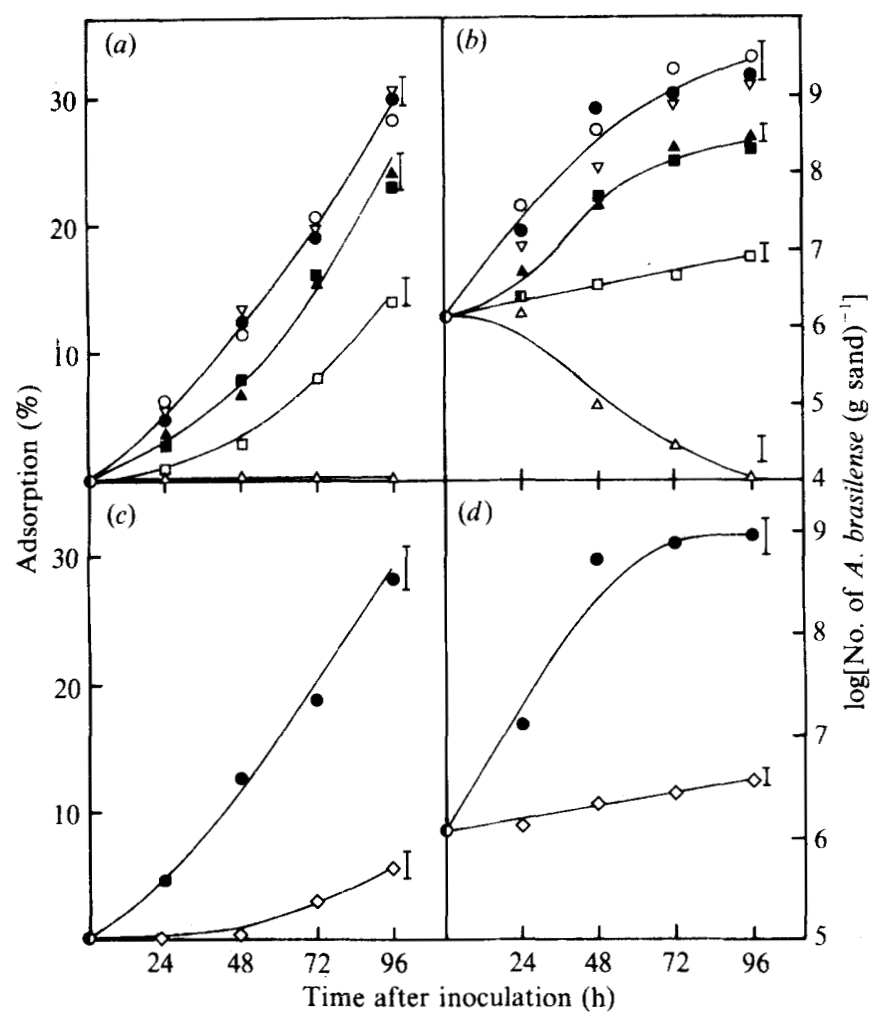

Fig. 6. Adsorption of $A$. brasilense Cd to sand in the presence of bacterial-inhibiting substances $(a)$ and high temperature $(c)$ and the respective bacterial numbers developed in the sand at the same time $(b, d)$. 0 . No addition; $O$, streptomycin sulphate $\left(200 \mathrm{mg} \mathrm{l}^{-1}\right) ; \Delta, 2,3,5$-triphenyltetrazolium chloride (15 $\left.\mathrm{mg} \mathrm{l}^{-1}\right) ; 0$, neomycin sulphate $\left(200 \mathrm{mg} \mathrm{l}^{-1}\right) ; \triangle, \mathrm{KCN}\left(5 \mathrm{mg} \mathrm{l}^{-1}\right) ; \triangle, \mathrm{KCN}\left(120 \mathrm{mg} \mathrm{l}^{-1}\right)$ or methyl violet $\left(60 \mathrm{mg} \mathrm{l}^{-1}\right)$ or tetracycline $\left(200 \mathrm{mg} \mathrm{l}^{-1}\right)$ or chloramphenicol $\left(250 \mathrm{mg} \mathrm{l}^{-1}\right) ; \square, \mathrm{NaN}_{3}\left(10 \mathrm{mg} \mathrm{l}^{-1}\right)$; $\diamond, 42^{\circ} \mathrm{C}$. All adsorption assays were done in the presence of fructose and $\mathrm{NH}_{4} \mathrm{Cl}$ as in Fig. 1. Bars represent the standard error of the lines.

\section{DISCUSSION}

The main features of pure quartz sand of significance in its adsorption of bacteria are its small surface area and its negligible amounts of clays and organic matter, with the latter two soil fractions having the greatest impact on bacterial adsorption. These characteristics result in minimal surface charge properties of the sand. Thus, the degree of adsorption of bacteria to sand particles cannot be evaluated in terms used to describe adsorption of bacteria to soil particles, i.e. charge-charge adsorption. Therefore, any significant permanent adsorption prevailing between sand particles and bacteria should be mediated by means of polymer bridging, which ensures that the bacteria remained attached even when substantial sheer forces are applied (Marshall, 1971, 1975; Marshall \& Bitton, 1980).

A. brasilense $\mathrm{Cd}$ is capable of active adsorption on to wheat root by polymer fibrillar bridges (Bashan et al., 1986). In addition, Fehrmann \& Weaver (1978) demonstrated the attachment of two rhizobia species to silt particles by a network of fibrillar material. Tyler \& Marshall (1967) suggested that soil bacteria produce some holdfast material to give more permanent binding to the surface. Fraser \& Gilmour (1986) reported that visible fibrillar material is an artefact of sample preparation, but accumulating electron microscopy data, obtained by use of different techniques in various bacteria-surface interactions, are not in accordance with this opinion (Foster, 1986).

Azospirillum forms massive aggregates when grown in liquid medium (Madi et al., 1986; Tarrand et al., 1978) or on the root surface (Bashan et al., 1986). Addition of fructose and $\mathrm{NH}_{4} \mathrm{Cl}$ 
to the medium increase bacterial growth and protein production by $A$. brasilense (Das $\&$ Mishra, $1983,1984)$. However, addition of $A$. brasilense Cd to sand in the chronic nutrient-deficiency conditions of soil result in a relatively small, weak adsorption of bacteria (Bashan \& Levanony, 1988; Marshall, 1980). This study demonstrates that by slightly manipulating the nutritional status of the sand, one can markedly change the attachment phenomenon. Although the strength of bacterial binding to sand particles remained weak, the rate of desorption of $A$. brasilense $\mathrm{Cd}$ cells from the particles was slower, perhaps as a result of the production of massive aggregates. However, these micro-colonies failed to aggregate the quartz particles as suggested by Lynch \& Bragg (1985) and for rhizobial aggregation of silt particles in the presence of nutrients as suggested by Fehrmann \& Weaver (1978). This may result from the fact that quartz particles are much larger than silt particles and thus do not normally aggregate. Aggregation of $A$. brasilense $\mathrm{Cd}$ on sand was stronger when there were sufficient nutrients to support growth. Starved bacteria probably only survived for a limited period of time, since they had no excess energy with which to produce fibrillar material. In the experiments supporting this study, the bacteria were grown in the presence of combined nitrogen, a treatment which prevented production of excess poly- $\beta$-hydroxybutyrate (PHB). The usual storage of intracellular PHB eliminated the possibility of synthesizing fibrillar material made of protein (Das \& Mishra, 1984). Therefore, it seems that the energy used to produce the attachment polymer bridges was obtained from nutrients supplied in the sand. Such conditions rarely occur in natural soil (Marshall, 1980), and are only possible in the presence of plants excreting nutrients (Ayers \& Thornton, 1968; Bashan, $1986 d$ ).

Live active cells of $A$. brasilense $\mathrm{Cd}$ are needed to form aggregates either in liquid culture (Madi et al., 1986) or on plant roots (Bashan et al., 1986). Dead cells adsorb minimally to sand and to roots, but do adsorb to soil particles (Bashan \& Levanony, 1988). This study suggests that in order to colonize marginal ecosystems, such as quartz sand, the bacteria should be in good metabolic condition, thus permitting production of external fibrillar material which is an essential feature for survival in this ecosystem. This type of relationship between $A$. brasilense $\mathrm{Cd}$ and sand is in contrast to the fact that most soil bacteria survived in the soil in a permanent adsorbed state. Application of soil bacteria even in extremely high numbers to soil resulted in their adsorption. However, the numbers of adsorbed rhizosphere bacteria were much lower than the number of soil-originated bacteria (Daniels, 1980). However, the numbers of associative $\boldsymbol{A}$. brasilense $\mathrm{Cd}$ that adsorbed to soil particles resembled the numbers of soil bacteria adsorbed $\left.\left[10^{8}-10^{9} \text { c.f.u. (g soil }\right)^{-1}\right]$. Compared to these numbers, even with the addition of nutrients to the sand, the numbers and percentage adsorption were smaller in sand than with any soil.

The chemical composition of the fibrillar material by which rhizosphere bacteria were bound to soil surfaces varied. In other studies, two species of rhizobia were bound to silt particles by a polysaccharide matrix (Fehrmann \& Weaver, 1978). In liquid culture, aggregates of $A$. brasilense $\mathrm{Cd}$ were formed by protein connections (Madi et al., 1986). In these reports, the materials were being synthesized in an aqueous solution, and thus only water-stable binding between particles and bacteria could form. In the case of $A$. brasilense $C d$ applied to sand, the circumstantial evidence presented in this study shows that a proteinaceous compound(s) may be involved in binding. Substances that inhibited protein synthesis or bacterial growth, protease and EDTA treatments, all decreased attachment.

Production and strength of the fibrillar material is dependent on several factors. Slow mixing for several hours of rhizobia with silt particles in aqueous solution resulted in formation of fibrillar material between bacteria and silt (Fehrmann \& Weaver, 1978). Growth of $A$. brasilense $\mathrm{Cd}$ for $16 \mathrm{~h}$ at 250 r.p.m. in shallow grooved Erlenmeyer flasks resulted in no self-aggregation (unpublished). The present study shows that when bacteria and sand were thoroughly agitated there was a significant reduction in attachment. It is suggested that the synthesis of this fibrillar material by the bacterium is a slow process, and strong agitation of the cells in the mixture eliminates the chance of possible attachment as a result of fibrillar rupture. On the other hand, these conditions increased the number of cells as a result of improved aeration. Furthermore, attachment under microaerophilic $\mathrm{N}_{2}$-fixing conditions was found to be lower than under aerobic conditions. It is known that the bacterial cell invests energy in the $\mathrm{N}_{2}$-fixing process, 
and perhaps when nutrients are limited the cell cannot support production of excess fibrillar material with the limited amount of energy available. Support for this theory is found in the fact that an increase in the nutrient content of the sand-bacteria mixture under these growth conditions resulted in increased adsorption.

The behaviour of $A$. brasilense $\mathrm{Cd}$ in light-textured soil followed similar trends. However, the magnitude of the phenomenon observed was much smaller than in sand indicating that other forces play a major role in adsorption of $A$. brasilense Cd to soil (Bashan \& Levanony, 1988).

Based on this and on a previous study (Bashan \& Levanony, 1988), it is proposed that adsorption to quartz sand is a weak, active process possibly carried out via protein bridges produced by the bacteria and usually controlled by the amount of nutrients available. It is also proposed that since adsorption of $A$. brasilense Cd to sand is weak, and in low numbers in the absence of external nutrients, plant inoculation should be tested in sand nurseries to eliminate the unwanted strong soil and peat adsorption prevailing to date in inoculation technology.

This study was written in memory of the late Mr Avner Bashan and was partially supported by an Eshkol fellowship from the Ministry of Science and Development to the senior author. We thank S. Dolberg from the Fenzia Co. at Yeruham Crater for donating pure quartz sand. Y. Bashan is the incumbent of the William T. Hogan and Winifred T. Hogan Career Development Chair.

\section{REFERENCES}

AYERs, W. A. \& ThornTon, R. H. (1968). Exudation of amino acids by intact and damaged roots of wheat and peas. Plant and Soil 28, 193-207.

BASHAN, Y. (1986a). Enhancement of wheat roots colonization and plant development by Azospirillum brasilense $\mathrm{Cd}$ following temporary depression of the rhizosphere microflora. Applied and Environmental Microbiology 51, 1067-1071.

BashaN, Y. $(1986 b)$. Alginate beads as synthetic inoculant carriers for the slow release of bacteria that affect plant growth. Applied and Environmental Microbiology 51, 1089-1098.

BASHAN, Y. (1986c). Significance of timing and level of inoculation with rhizosphere bacteria on wheat plants. Soil Biology and Biochemistry 18, 297-301.

BASHAN, Y. (1986d). Migration of the rhizosphere bacteria Azospirillum brasilense and Pseudomonas fuorescens towards wheat roots in the soil. Journal of General Microbiology 132, 3407-3414.

BashaN, Y. \& LEVANONY, H. (1985). An improved selection technique and medium for the isolation and enumeration of Azospirillum brasilense. Canadian Journal of Microbiology 31, 947-952.

BaShan, Y. \& LEVANONY, H. (1988). Adsorption of the rhizosphere bacterium Azospirillum brasilense $\mathrm{Cd}$ to soil, sand and peat particles. Journal of General Microbiology 134, 1811-1820.

Bashan, Y., Levanony, H. \& Klein, E. (1986). Evidence for a weak active external adsorption of Azospirillum brasilense Cd to wheat roots. Journal of General Microbiology 132, 3069-3073.

DANIELS, S. L. (1980). Mechanisms involved in sorption of microorganisms to solid surfaces. In Adsorption of Microorganisms to Surfaces, pp. 7-58. Edited by G. Bitton \& K. C. Marshall. New York: John Wiley.
DAS, A. \& Mishra, A. K. (1983). Utilization of fructose by Azospirillum brasilense. Canadian Journal of Microbiology 29, 1213-1217.

DAS, A. \& MisHRA, A. K. (1984). Various physiological aspects associated with metabolism of fructose and malate in Azospirillum brasilense. Indian Journal of Experimental Biology 22, 536-538.

FehrmanN, R. C. \& Weaver, R. W. (1978). Scanning electron microscopy of Rhizobium spp. adhering to fine silt particles. Journal of the Soil Science Society of America 42, 279-281.

Foster, R. C. (1986). The ultrastructure of the rhizoplane and the rhizosphere. Annual Review of Phytopathology 24, 211-234.

Fraser, T. W. \& Gilmour, A. (1986). Scanning electron microscopy preparation methods: their influence on the morphology and fibril formation in Pseudomonas fragi (ATCC 4973). Journal of Applied Bacteriology 60, 527-533.

LeVANONY, H., Bashan, Y. \& Kahana, Z. E. (1987). Enzyme-linked immunosorbent assay for specific identification and enumeration of Azospirillum brasilense $\mathrm{Cd}$ in cereals roots. Applied and Environmental Microbiology 53, 358-364.

LYNCH, J. M. \& BRAGG, E. (1985). Microorganisms and soil aggregate stability. Advances in Soil Science 2, 133-171.

Madi, L., Kessel, M., Sadovnik, E. \& Henis, Y. (1986). Aggregation of Azospirillum sp. Fourth International Symposium on Microbial Ecology, Ljubljana, Yugoslavia, p. 119 (abstract).

Marshall, K. C. (1971). Sorptive interactions between soil particles and microorganisms. In Soil Biochemistry vol. 2, pp. 409-445. Edited by A. D. McLaren \& J. J. Skujins. New York: Marcel Dekker. 
Marshall, K. C. (1975). Clay mineralogy in relation to survival of soil bacteria. Annual Review of Phytopathology 13, 357-373.

MarshaLL, K. C. (1980). Adsorption of microorganisms to soils and sediments. In Adsorption of Microorganisms to Surfaces, pp. 317-329. Edited by G. Bitton \& K. C. Marshall. New York: John Wiley.

Marshall, K. C. \& Bitton, G. (1980). Microbial adhesion in perspective. In Adsorption of Microorganisms to Surfaces, pp. 1-5. Edited by G. Bitton \& K. C. Marshall. New York: John Wiley.

Ravikovitch, S. (1981). The Soils of Israel, Formation, Nature and Properties. Tel Aviv: Hakibbutz Hameuchad (in Hebrew).

SchaNk, S. C. \& SMITH, R. L. (1984). Status and evaluation of associative grass-bacteria $\mathrm{N}_{2}$-fixing systems in Florida. Proceedings of the Soil and Crop Science Society of Florida 43, 120-123.

Sedmak, J. J. \& Grossberg, S. E. (1977). A rapid, sensitive and versatile assay for protein using Coomassie brilliant blue G250. Analytical Biochemistry 79, 544-552.

TARRAND, J. J., KRIEG, N. R. \& DöberEINER, J. (1978). A taxonomic study on the Spirillum lipoferum group, with descriptions of a new genus, Azospirillum gen. nov. and two species, Azospirillum lipoferum (Beijerinck) comb. nov. and Azospirillum brasilense sp. nov. Canadian Journal of Microbiology 24, 967-980.

Tyler, P. A. \& Marshall, K. C. (1967). Form and function in manganese-oxidizing bacteria. Archiv für Mikrobiologie 56, 344-353. 